\title{
ANALISIS FAKTOR EKSTERNAL PEMBELAJARAN
}

Oleh:

\section{Ade Suhendra ${ }^{1}$}

\begin{abstract}
Abstrak
Kualitas proses pembelajaran ternyata dipengaruhi oleh berbagai faktor yang satu sama lain sama-sama memiliki pengaruh penting, secara umum dikategorikan sebagai faktor eksternal dan faktor internal. Makalah ini secara khusus ditujukan untuk membahas tentang faktor-faktor eksternal yang mempengaruhi proses belajar anak/individu. Faktor eksternal pembelajaran merupakan hal-hal yang berada di luar (dalam konteks ini di luar individu) yang mempengaruhi proses dan hasil pembelajaran. Faktor eksternal pembelajaran meliputi: kondisi keluarga, kondisi sosial (masyarakat), dan kondisi sekolah.
\end{abstract}

\begin{abstract}
The quality of learning process influenced by many factors that each other have is urgent, overall chategorized as the external and internal. This paper described about the external factors that influenced learning process of the students. The external factors in learning is anything outside (individual) that influenced process and result of learning. The external factors in learning is: family condition, social condition, and school condition.
\end{abstract}

Keywords: Pembelajaran, belajar, proses dan hasil pembelajaran

\footnotetext{
${ }^{1}$ Penulis adalah Dosen Program Studi Pendidikan Guru Madrasah Ibtidaiyah IAIN Padangsidimpun
} 


\section{Pendahuluan}

Salah satu indikator utama yang harus diperhatikan dalam mengukur kualitas pendidikan ialah pelaksanaan proses pembelajaran. Proses pembelajaran yang bermutu dan berkualitas tentu akan berimplikasi pada mutu dan kualitas proses pendidikan. Sehingga peningkatan kualitas pembelajaran menjadi suatu hal yang mutlak dilakukan sebagai upaya meningkatkan kualitas pendidikan. Sulit (untuk tidak mengatakan mustahil) proses pendidikan yang berkualitas akan tercapai, tanpa terlebih dahulu menciptakan proses pembelajaran yang berkualitas. Namun, kualitas proses pembelajaran ternyata dipengaruhi oleh berbagai faktor yang satu sama lain sama-sama memiliki pengaruh penting, secara umum dikategorikan sebagai faktor eksternal dan faktor internal.

Makalah ini secara khusus ditujukan untuk membahas tentang faktor-faktor eksternal yang mempengaruhi proses belajar anak/individu. Dengan kata lain, makalah ini akan menguraikan secara gamblang dan mendalam tentang segala hal yang berada di luar individu si pembelajar yang berpotensi mempengaruhi proses belajar, baik dari segi lingkungan keluarga, sekolah, dan masyarakat. Adanya keterkaitan dan keterpaduan antara ketiga lingkungan tersebut, mengakibatkan faktor-faktor yang mempengaruhi proses pembelajaran menjadi bahasan yang sangat kompleks dan memerlukan kajian yang mendalam. Dengan demikian, tulisan ini hanya merupakan kajian awal tentang faktor eksternal pembelajaran.

\section{Pembahasan}

\section{Pengertian Faktor Eksternal Pembelajaran}

Faktor eksternal pembelajaran merupakan gabungan tiga kata yang membentuk suatu pemahaman tertentu. Faktor secara sederhana dapat diartikan sebagai hal-hal yang menyebabkan/mempengaruhi terjadinya sesuatu. Eksternal berarti di luar (individu), dan pembelajaran yaitu proses interaksi antara peserta didik dengan pendidik dan lingkungannya dalam rangka pelaksanaan pendidikan.

Dengan demikian, faktor eksternal pembelajaran dapat dipahami sebagai hal-hal yang berada di luar (dalam konteks ini di luar individu) yang mempengaruhi proses dan hasil pembelajaran. Hal ini sesuai dengan yang diungkapkan oleh Slameto dalam Belajar dan Faktor-faktor yang Mempengaruhinya bahwa faktor ekstern adalah faktor yang berada di luar individu yang sedang belajar. Knud Illeris juga menambahkan bahwa kondisi 
eksternal pembelajaran adalah karakteristik di luar diri pembelajar yang mempengaruhi peluang pembelajaran dan terlibat dalam proses pembelajaran. ${ }^{2}$

Ibarat menanam sebuah tanaman yang baik dan subur, maka perlu dikaji terlebih dahulu faktor-faktor yang mempengaruhi baik dan suburnya suatu tanaman. Sehingga proses penanaman akan dilaksanakan sesuai dengan hasil kajian tersebut. Akan sulit untuk menanam sebuah tanaman yang baik dan subur tanpa diketahui di mana tanaman tersebut sebaiknya ditanam, bagaimana pupuk yang baik, bagaimana pengairannya, dan lain sebagainya. Demikian halnya dengan pembahasan tentang faktor-faktor yang mempengaruhi pembelajaran tentunya menjadi kajian penting dalam upaya menciptakan proses pembelajaran yang berkualitas, sehingga melalui proses pembelajaran yang berkualitas ini akan tercapai pula proses pendidikan yang berkualitas.

\section{Faktor Eksternal Pembelajaran}

Slameto $^{3}$ mengelompokkan faktor eksternal yang mempengaruhi pembelajaran menjadi 3 faktor, yaitu faktor keluarga, faktor sekolah dan faktor masyarakat. Berikut bahasan mengenai ketiga hal tersebut.

a. Faktor Keluarga

Faktor keluarga dalam hal ini berupa: Pertama, cara mendidik anak memiliki pengaruh yang besar terhadap bagaimana anak tersebut berinteraksi dalam proses pembelajaran. Keluarga merupakan lingkungan pertama yang dihadapi anak semenjak lahir. Sehingga, kepribadian anak mutlak dipengaruhi oleh bagaimana anak tersebut dididik oleh orang tua. Demikian halnya juga dengan bagaimana orang tua memberikan fasilitas untuk belajar dan mengawal proses perkembangan anak merupakan tugas yang tidak bisa dibebankan kepada orang lain begitu juga kepada sekolah. Karena sekolah pada hakikatnya, hanya bertugas untuk melanjutkan hasil didikan orang tua. Ragam kewajiban orang tua tersebut misalnya memperhatikan kepentingan-kepentingan dan kebutuhan-kebutuhan anak dalam belajar, mengatur waktu belajar, menyediakan/melengkapi alat belajar, mengetahui kemampuan belajar anak dan kesulitan-kesulitan yang dialami anak dalam belajar, dsb.

Fenomena saat ini menunjukkan bahwa proses pendidikan anak cenderung diberikan secara penuh pada lembaga-lembaga pendidikan formal, orang tua seolah-olah merasa tidak memiliki peranan dalam membentuk kepribadian anaknya. Sebagai contoh, ketika ada usaha guru untuk

\footnotetext{
${ }^{2}$ Knud Illeris, Contemporary Theories of Learning, (Bandung: Nusa Media, 2011), hlm. 22.

3 Slameto, Belajar dan Faktor-Faktor yang Mempengaruhinya (Jakarta: Rineka Cipta, 2003), hlm. 60-72.
} 
berkomunikasi dengan orang tua mengenai perkembangan peserta didik, sebagian besar orang tua terkesan merasa 'acuh tak acuh', tidak memiliki kepedulian terhadap perkembangan anaknya di sekolah. Sekolah diberikan wewenang penuh dalam mendidik anak. Hal ini tentunya merupakan pandangan yang keliru, sebab yang seharusnya menjadi pembimbing utama atau penanggungjawab pendidikan anak yang pertama dan utama adalah orang tua dalam keluarga.

Kedua, relasi antar anggota keluarga, dalam hal ini berupa relasi antara anak dengan orang tua, saudara-saudaranya, dan anggota keluarga lain. Hal ini juga mempengaruhi belajar anak. Hubungan yang penuh pengertian dan kasih sayang antar semua anggota keluarga akan memberikan dampak positif terhadap sikap anak dalam berinteraksi dalam proses pembelajaran. Akan berbeda halnya jika yang terjadi justru sebaliknya, yaitu hubungan antara orang tua dengan anak, antara anak dengan sudaranya, dan dengan anggota keluarga lain tidak harmonis, saling membenci, tentunya hal ini akan mempengaruhi proses belajar anak.

Ketiga, suasana rumah. Hal ini hampir mirip dengan yang kedua, namun suasana rumah dalam hal ini lebih mengarah pada kondisi fisik anak. Misalnya suasana rumah yang nyaman dan tidak ramai tentunya akan memberikan ketenangan kepada anak untuk belajar. Suasana rumah yang lembut, tidak ribut, tidak ada percekcokan dan pertengkaran antar keluarga atau dengan keluarga lain tentunya akan menyebabkan anak menjadi betah di rumah, dan proses belajarnya pun akan lancar.

Keempat, keadaan ekonomi keluarga erat kaitannya dengan belajar anak. Anak yang sedang belajar di samping kebutuhan pokoknya harus dipenuhi, seperti makan, pakaian, kesehatan,dsb., juga membutuhkan fasilitas belajar seperti ruang belajar, meja, kursi, penerangan, alat tulis-menulis, bukubuku dsb. Dengan memenuhi berbagai kebutuhan tersebut, maka proses belajar anak pun akan semakin lancar. Sebaliknya, tanpa dipenuhinya berbagai kebutuhan tersebut akan mengakibatkan proses belajar anak akan terganggu.

b. Faktor Sekolah

Faktor sekolah yang mempengaruhi belajar ini mencakup: pertama, metode pembelajaran memiliki pengaruh besar terhadap proses pembelajaran. Guru yang memiliki variasi metode pembelajaran akan menghindarkan siswa dari kebosanan, sehingga proses pembelajaran pun akan menggairahkan peserta didik. Kemahiran guru dalam mengorganisir semua informasi yang telah tersedi dalam berbagai media, dan menyajikannya dalam proses pembelajaran 
yang menyenangkan akan berperan penting terhadap perkembangan proses belajar anak.

Kedua, kurikulum dalam arti sejumlah kegiatan yang diberikan kepada siswa. Kurikulum yang baik misalnya kurikulum yang tidak terlalu padat, sesuai kemampuan, bakat, minat dan perhatian siswa. Berkenaan dengan hal ini, Nana Syaodih Sukmadinata ${ }^{4}$ menjelaskan bahwa kurikulum sekolah harus berlandaskan pada aspek psikologis siswa. Kondisi psikologis setiap individu berbeda, dikarenakan perbedaan tahap perkembangannya, latar belakang sosial budaya, juga karena perbedaan faktor-faktor yang dibawa dari kelahirannya.

Ketiga, relasi antara guru dengan siswa juga akan berpengaruh terhadap proses pembelajaran. Terjalinnya relasi yang akrab dan santun antara guru dan siswa akan menjadikan pembelajaran berlangsung hangat serta menarik minat siswa. Mengenai kedekatan hubungan antara guru dengan siswa Moh. Roqib ${ }^{5}$ menjelaskan bahwa guru merupakan wakil orang tua siswa di sekolah untuk mengemban proses pendidikan anak-anaknyan pada saat anak-anak tersebut berada di lembaga pendidikan. Dengan demikian, sudah sepatutnyalah guru mampu memposisikan dirinya layaknya orang tua asli siswa, sehingga proses pembelajaran berlangsung dengan dekat serta menggairahkan siswa.

Keempat, relasi siswa dengan siswa juga penting untuk diperhatikan, antara siswa diharapkan tidak ada perselisihan. Melainkan harus berjalan secara harmonis, agar dapat memberikan pengaruh yang positif terhadap belajar siswa. Kelima, disiplin sekolah yang meliputi kedisiplinan guru dalam mengajar, kedisiplinan pegawai/karyawan dalam melaksanakan tugas adminstrasi, kebersihan/keteraturan kelas, gedung sekolah, halaman, selain membuat disiplin siswa, juga memberi pengaruh positif terhadap belajarnya. Selain itu juga akan menumbuhkan sikap bertanggung jawab pada anak.

c. Faktor Masyarakat

Masyarakat merupakan faktor ekstern yang juga berpengaruh terhadap belajar siswa. Hal ini meliputi, Pertama, kegiatan siswa dalam masyarakat yang bersifat positif akan berdampak positif pula bagi proses belajarnya, terlebih lagi kemampuan bersosialisasi. Namun tentunya harus bijaksana mengatur waktu agar waktu tidak mengganggu waktu belajarnya. Seperti kegiatan anak dalam organisasi kepemudaan, tentunya akan berdampak positif terhadap

${ }^{4}$ Nana Syaodih Sukmadinata, Pengembangan Kurikulum: Teori dan Praktek (Bandung: Remaja Rosdakarya, 2010), hlm. 45.

${ }^{5}$ Moh. Roqib, Ilmu Pendidikan Islam: Pengembangan Pendidikan Integratif di Sekolah, Keluarga, dan Masyarakat (Yogyakarta: LKiS, 2009), hlm. 42. 
perkembangan belajar anak. Namun jika anak hanya berfokus pada organisasi kepemudaan tersebut, makan akan berakibat negatif juga terhadap belajar anak.

Kedua, Mass media yang meliputi bioskop, radio, TV, surat kabar, majalah, buku-buku, komik-komik, dsb., yang semua itu beredar dalam masyarakat. Mass media yang baik tentunya akan berpengaruh positif bagi proses belajar anak, begitu juga sebaliknya mass media yang tidak baik akan berdampak tidak baik pula bagi belajar anak. Teresa Orange dan louise O'Flynn mengungkapkan beberapa bahaya media terhadap anak, yaitu: (1) perubahan perilaku anak menjadi anti sosial, (2) sikap anak yang tanpa keraguan untuk meniru berbagai hal, (3) menjadikan tingkat toleransi anak menjadi rendah/mudah prustasi, (4) membuat anak bersikap apatis terhadap mainan atau membatasi kemampuan anak untuk bermain secara imajinatif, (5) menimbulkan rasa depresi dan rendah diri, (6) membuat anak terlalu cepat dewasa, (7) membuat kesehatan fisik anak menurun. Berbagai faktor di atas, membuat peran media terhadap proses belajar anak akan terganggu. ${ }^{6}$

Ketiga, teman bergaul anak sangat penting untuk diperhatikan. Dengan bergaul dengan teman positif akan berpengaruh besar terhadap belajar anak, berbeda halnya jika anak bergaul dengan teman yang negatif akan berpengaruh besar terhadap belajar anak. Kepribadian anak erat kaitannya dengan siapa anak bergaul dan berteman. Sehingga perlu diperhatikan teman bergaul anak, bila teman-temannya kebanyakan sudah merokok, maka besar kemungkinan anak akan merokok juga. Jika teman-temannya rajin membaca, maka anak pun kemungkinan besar akan rajin membaca.

Keempat, bentuk kehidupan masyarakat. Kondisi lingkungan yang positif, berpendidikan, damai, tenteram, akan memberi dampak positif bagi belajar anak disebabkan kondisi masyarakat yang mendorongnya untuk belajar dengan baik. Suasana lingkungan rumah yang berada di sekitar pasar/terminal/tempattempat hiburan akan berbeda dengan di daerah khusus pemukiman. Suasana rumah di lingkungan pemukiman yang padat dan kurang tertata, juga berbeda dengan pemukiman yang jarang dan tertata. Sehingga suasana dan kondisi lingkungan tertentu akan mempengaruhi perkembangan belajar anak. Kondisi lingkungan keluarga yang aman, tentram, tidak gaduh, tidak ribut, damai, khusus pemukiman, akan berpotensi memberikan dampak positif bagi perkembangan belajar anak. Akan berbeda halnya dengan apabila anak berada

${ }^{6}$ Teresa Orange dan Louise O'Flynn, The Media Diet for Kids (Jakarta: Serambi, 2007), hlm. 35-84. 
di lingkungan yang ribut, dekat pasar, terminal, padat penduduk, kondisi demikian berpotensi memberikan dampak negatif terhadap perkembangan anak.

Kelima, lingkungan sekolah juga memegang peranan penting terhadap perkembangan belajar para siswanya. Lingkungan ini meliputi lingkungan fisik sekolah seperti lingkungan kampus, sarana prasarana belajar yang ada, sumbersumber belajar, media belajar dsb., lingkungan sosial yang menyangkut hubungan siswa dengan teman-temannya, guru-gurunya serta staf sekolah lainnya. Lingkungan sekolah juga menyangkut lingkungan akademis, yaitu suasana dan pelaksanaan kegiatan belajar-mengajar, berbagai kegiatan ekstrakurikuler, dsb. Sekolah yang kaya dengan aktivitas belajar, memiliki sarana dan prasarana yang memadai, terkelola dengan baik, diliputi suasana akademis yang wajar, akan sangat mendorong semangat belajar para siswanya.

Hal penting yang sering menjadi faktor keberhasilan pendidikan anak dalam lingkungan sekolah seperti: sikap dan kepribadian guru, tinggi rendahnya pengetahuan yang dimiliki guru, dan bagaimana cara guru itu mengajarkan pengetahuan itu kepada anak-anak didiknya, turut menentukan bagaimana hasil belajar yang dapat dicapai oleh anak. Sehingga proses pendidikan seringkali berlangsung seadanya saja, tanpa perencanaan yang matang. Jikapun direncanakan, apa yang dilaksanakan di lapangan belum sesuai dengan yang direncanakan. ${ }^{7}$

Lebih lanjut, Muhibbin Syah mengungkapkan bahwa lingkungan sekolah seperti para guru, staf adminstrasi, dan teman-teman sekelas dapat mempengaruhi semangat belajar siswa. Para guru yang selalu menunjukkan sikap dan perilaku yang simpatik serta mempercontohkan suri teladan yang baik dan rajin khususnya dalam hal belajar, misalnya rajin membaca dan berdiskusi, dapat menjadi daya dorong yang positif bagi kegiatan belajar siswa. Semangat siswa akan terdongkrak oleh iklim yang dibentuk oleh guru tersebut. ${ }^{8}$

Padahal, berkaitan dengan peran penting guru dalam pembelajaran sebagaimana diungkapkan Ahmad Barizi bahwa guru (diakui atau tidak) akan selalu menjadi unsur penting yang akan menentukan berhasil tidaknya pendidikan. Meskipun pendekatan CBSA, Manajemen Berhasil Sekolah (School Based Management), dan KBK (Kurikulum Berbasis Kompetensi) memang

${ }^{7}$ M. Ngalim Purwanto, Psikologi Pendidikan (Bandung: Remaja Rosdakarya, 2007), hlm. 104-105.

${ }^{8}$ Muhibbin Syah, Psikologi Pendidikan Dengan Pendekatan Baru (Bandung: Remaja Rosdakarya, 2007), hlm. 137. 
menekankan pada aktivitas dan kompetensi peserta didik ketimbang guru. Namun pada kenyataannya keterlibatan (commitment) guru masih sangat dominan (tak tergantikan) dalam menentukan berhasil tidaknya proses pembelajaran. Oleh sebab itu, apapun formulasi para pemandu dan pakar pendidikan mengenai strategi proses pendidikan dan pembelajaran, mau tidak mau harus menempatkan guru dalam posisi strategis di dalamnya. ${ }^{9}$

Wina Sanjaya melanjutkan bahwa guru merupakan komponen yang menentukan dalam keberhasilan suatu sistem pembelajaran. Hal ini disebabkan guru merupakan orang yang secara langsung berhadapan dengan siswa. Dalam sistem pembelajaran guru bisa berperan sebagai perencana (planer) atau desainer (designer) pembelajaran, sebagai implementator dan atau mungkin keduanya. Sebagai perencana guru dituntut untuk memahami secara benar kurikulum yang berlaku, karakteristik siswa, fasilitas dan sumber daya yang ada, sehingga semuanya dijadikan komponen-komponen dalam menyusun rencana dan desain pembelajaran. ${ }^{10}$

Keenam, lingkungan sebagaimana diungkapkan Iskandar merupakan salah satu sumber belajar yang amat penting dan memiliki nilai-nilai yang sangat berharga dalam rangka proses pembelajaran siswa dan dapat memperkaya bahan dan kegiatan belajar. lingkungan masyarakat di mana siswa berada juga berpengaruh terhadap semangat dan aktivitas belajarnya. ${ }^{11}$ Lingkungan (environment) sebagai dasar pengajaran merupakan faktor kondisional yang mempengaruhi tingkah laku individu dan merupakan faktor belajar yang penting. Lingkungan belajar terdiri dari:

1) Lingkungan sosial adalah lingkungan masyarakat baik kelompok besar atau kelompok kecil.

2) Lingkungan personal meliputi individu-individu sebagai suatu pribadi berpengaruh terhadap individu pribadi lainnya.

3) Lingkungan alam (fisik) meliputi semua sumber daya alam yang dapat diberdayakan sebagai sumber belajar.

4) Lingkungan kultural mencakup hasil budaya dan teknologi yang dapat dijadikan sumber belajar dan yang dapat menjadi faktor pendukung

${ }^{9}$ Ahmad Barizi, Pendidikan Integratif: Akar Tradisi \& Integrasi Keilmuan Pendidikan Islam (Malang: UIN-Maliki Press, 2011), hlm. 25-26.

${ }^{10}$ Wina Sanjaya, Perencanaan dan Desain Sistem Pembelajaran (Jakarta: Kencana, 2011), hlm. 15-16.

${ }^{11}$ Iskandar, Psikologi Pendidikan: Sebuah Orientasi Baru (Ciputat: Gaung Persada, 2009), hlm. 205. 
pembelajaran. Dalam konteks ini termasuk sistem nilai, norma, dan adat kebiasaan. $^{12}$

Lingkungan masyarakat di mana warganya memiliki latar belakang pendidikan yang cukup, terdapat lembaga-lembaga pendidikan dan sumbersumber belajar di dalamnya akan memberikan pengaruh yang positif terhadap semangat dan perkembangan belajar generasi mudanya.

Kondisi masyarakat pada lingkungan yang kumuh, serba kekurangan dan anak-anak pengangguran, misalnya, akan sangat mempengaruhi aktivitas belajar siswa. setidaknya, dalam situasi demikian, siswa akan menemukan kesulitan ketika memerlukan teman belajar, berdiskusi, atau meminjam alat-alat belajar tertentu yang kebetulan belum dimilikinya. ${ }^{13}$ Pada lingkungan masyarakat, sebagaimana diungkapkan Abdul Hadis bahwa peranan tokoh masyarakat dan pemerintah juga sangat besar dalam memfasilitasi serta mendukung proses belajar anak. Karisma tokoh masyarakat misalnya sangat dibutuhkan untuk menjadi inspirasi atau contoh teladan bagi anak untuk belajar nyaman dan memberikan perubahan yang berarti bagi masyarakat. ${ }^{14}$

Sumadi Suryabrata mengungkapkan bahwa faktor-faktor yang berasal dari luar diri pelajar dapat digolongkan kepada dua macam, yaitu:

1) Faktor-faktor nonsosial, kelompok faktor-faktor ini dikatakan tak terbilang jumlahnya, seperti misalnya: keadaan suhu, cuaca, waktu (pagi, siang, atau malam), tempat (letak gedungnya), alat-alat yang dipakai untuk belajar (alat tulis-menulis, buku-buku, alat-alat peraga, dan sebagainya yang biasa disebut sebagai alat-alat pelajaran).

2) Faktor-faktor sosial yaitu faktor manusia (sesama manusia). Kehadiran orang atau orang-orang lain pada waktu sedang belajar, akan mengganggu belajar anak; atau misalnya lagi, kalau satu kelas murid sedang mengerjakan ujian, lalu terdengar banyak anak-anak lain bercakap-cakap di samping kelas, tentunya kondisi demikian akan mengganggu konsentrasi murid untuk belajar. ${ }^{15}$

Berkaitan dengan faktor eksternal, Baharuddin menambahkan adanya faktor nonsosial yang dapat mempengaruhi proses belajar siswa, meliputi: pertama, lingkungan alamiah, seperti kondisi udara yang segar, tidak panas dan tidak dingim, sinar yang tidak terlalu silau/kuat, atau juga tidak terlalu

${ }^{12}$ Oemar Hamalik, Proses Belajar Mengajar (Jakarta: Bumi Aksara, 2010), hlm. 195-196.

${ }^{13}$ Muhibbin Syah, Psikologi..., hlm.137.

${ }^{14}$ Abdul Hadis, Psikologi dalam Pendidikan (Bandung: Alfabeta, 2006), hlm.66.

${ }^{15}$ Sumadi Suryabrata, Psikologi Pendidikan (Jakarta: Rajawali Press, 2011), hlm. 233-234. 
lemah/gelap, suasana yang sejuk dan tenang. Lingkungan alamiah tersebut tentunya dapat mempengaruhi aktivitas belajar siswa. Bila lingkungan alamiah mendukung maka akan berdampak positif terhadap proses belajar anak, dan sebaliknya bila kondisi lingkungan alam tidak mendukung, maka proses belajar siswa akan terhambat.

Kedua, faktor instrumental yang dapat digolongkan menjadi dua macam, yaitu hardware dan software. Hardware, seperti gedung sekolah, alat-alat belajar, fasilitas belajar, lapangan olahraga, dan lain sebagainya. Software, seperti kurikulum sekolah, peraturan-peraturan sekolah, buku panduan, silabus, dsb.

Ketiga, materi pelajaran yang diajarkan pada siswa. Pemilihan materi dan metode mengajar guru hendaknya disesuaikan dengan kondisi perkembangan siswa. Dengan demikian, guru seharusnya menguasai materi pelajaran dan berbagai metode yang dapat diterapkan sesuai kondisi siswa. ${ }^{16}$

Secara rinci, Abin Syamsuddin Makmun menjelaskan tentang faktorfaktor yang terletak di luar diri siswa (situasi sekolah dan masyarakat) yang dapat mempengaruhi proses belajar siswa, antara lain:

1) Kurikulum yang seragam (uniform), bahan dan buku-buku sumber yang tidak sesuai dengan tingkat-tingkat kematangan dan perbedaan-perbedaan individu;

2) Ketidaksesuaian standar adminstratif (sistem pengajaran), penilaian, pengelolaan kegiatan dan pengalaman belajar-mengajar, dan sebagainya;

3) Terlalu berat beban belajar (siswa) dan/atau mengajar (guru);

4) Terlalu besar populasi siswa dalam kelas, terlalu banyak menuntut kegiatan di luar, dan sebagainya;

5) Terlalu sering pindah sekolah atau program, tinggal kelas, dan sebagainya;

6) Kelemahan dari sistem belajar-mengajar pada tingkat-tingkat pendidikan (dasar/asal) sebelumnya;

7) Kelemahan yang terdapat dalam kondisi rumah tangga (pendidikan, status sosial ekonomis, keutuhan keluarga, besarnya anggota keluarga, tradisi dan kultur keluarga, ketenteraman dan keamanan sosial psikologis dan sebagainya);

8) Terlalu banyak kegiatan di luar jam pelajaran sekolah atau terlalu banyak terlibat dalam kegiatan ekstrakurikuler;

${ }^{16}$ Baharuddin dan Esa Nur Wahyuni, Teori Belajar dan Pembelajaran (Jogjakarta: Ar-Ruzz Media, 2010), hlm. 27-28. 
9) Kekurangan makan (gizi, kalori, dan sebagainya). ${ }^{17}$

Sebagai pertimbangan lain, Fuad Ihsan secara umum mengidentifikasi berbagai faktor pendidikan, yang pada hakikatnya juga bisa dikategorikan sebagai faktor eksternal pembelajaran, yaitu:

1) Tujuan, yaitu harapan yang ingin dicapai setelah proses pembelajaran.

2) Pendidik, dalam arti tidak hanya guru yang berposisi sebagai pendidik, melainkan orang tua juga dikatakan sebagai pendidik (bahkan pendidik utama).

3) Peserta didik, yaitu individu yang sedang melakukan proses pembelajaran (pelaku utama).

4) Isi/materi pendidikan, yaitu muatan pendidikan yang ingin dikuasai oleh peserta didik.

5) Metode Pendidikan, yaitu cara pendidik/guru dalam menyampaikan atau melakukan proses pembelajaran untuk mencapai tujuan pendidikan.

6) Situasi Lingkungan, yaitu baik berupa lingkungan keluarga, antar sesama teman, lingkungan masyarakat, dan lingkungan sekolah. ${ }^{18}$

Berdasarkan penjelasan di atas, dapat dipahami bahwa kolaborasi antara suatu faktor dengan faktor lainnya akan menjadi pengaruh besar terhadap perkembangan proses belajar siswa. Dengan memperhatikan berbagai faktorfaktor yang mempengaruhi proses pembelajaran, dan men-setting faktor eksternal yang mendukung proses belajar anak, maka upaya menciptakan proses pembelajaran yang berkualitas akan terwujud.

\section{Kesimpulan}

1. Faktor eksternal pembelajaran merupakan hal-hal yang berada di luar (dalam konteks ini di luar individu) yang mempengaruhi proses dan hasil pembelajaran.

2. Faktor eksternal pembelajaran meliputi: kondisi keluarga, kondisi sosial (masyarakat), dan kondisi sekolah.

17 Abin Syamsuddin Makmun, Psikologi Kependidikan: Perangkat Sistem Pengajaran Modul (Bandung: Remaja Rosdakarya, 2005), hlm. 21.

${ }^{18}$ Fuad Ihsan, Dasar-Dasar Kependidikan (Jakarta: Rineka Cipta, 2010), hlm. 7-10. 


\section{Referensi}

Baharuddin dan Esa Nur Wahyuni, Teori Belajar dan Pembelajaran, Jogjakarta: Ar-Ruzz Media, 2010.

Barizi, Ahmad, Pendidikan Integratif: Akar Tradisi \& Integrasi Keilmuan Pendidikan Islam, Malang: UIN-Maliki Press, 2011.

Danim, Sudarman, Agenda Pembaruan Sistem Pendidikan, Yogyakarta: Pustaka Pelajar, 2006.

Djamarah, Syaiful Bahri, Psikologi Belajar, Jakarta: Rineka Cipta, 2011.

Hadis, Abdul, Psikologi dalam Pendidikan, Bandung: Alfabeta, 2006.

Hamalik, Oemar, Proses Belajar Mengajar, Jakarta: Bumi Aksara, 2004. , Dasar-Dasar Pengembangan Kurikulum, Bandung: Remaja Rosdakarya, 2009.

Ihsan, Fuad, Dasar-Dasar Kependidikan, Jakarta: Rineka Cipta, 2010.

Illeris, Knud, Contemporary Theories of Learning, Bandung: Nusa Media, 2011.

Iskandar, Psikologi Pendidikan: Sebuah Orientasi Baru, Ciputat: Gaung Persada, 2009.

Majid, Abdul, Perencanaan Pembelajaran: Mengembangkan Standar Kompetensi Guru, Bandung: Remaja Rosdakarya, 2005.

Makmun, Psikologi Kependidikan: Perangkat Sistem Pengajaran Modul, Bandung: Remaja Rosdakarya, 2005.

O'Flynn, Teresa Orange dan Louise, The Media Diet for Kids, Jakarta: Serambi, 2007.

Purwanto, M. Ngalim, Psikologi Pendidikan, Bandung: Remaja Rosdakarya, 2007. , Ilmu Pendidikan Teoretis dan Praktis, Bandung: Remaja Rosdakarya, 2011.

Riyanto, Yatim, Paradigma Baru Pembelajaran: Sebagai Referensi bagi Pendidik dalam Implementasi Pembelajaran yang Efektif dan Berkualitas, Jakarta: Kencana, 2010.

Roqib, Moh., Ilmu Pendidikan Islam: Pengembangan Pendidikan Integratif di Sekolah, Keluarga, dan Masyarakat, Yogyakarta: LKiS, 2009.

Sanjaya, Wina, Perencanaan dan Desain Sistem Pembelajaran, Jakarta: Kencana, 2011.

Slameto, Belajar dan Faktor-Faktor yang Mempengaruhinya, Jakarta: Rineka Cipta, 2003.

Slavin, Robert E., Psikologi Pendidikan: Teori dan Praktik, Jakarta: Indeks, 2009. 
Suhana, Nanang Hanafiah dan Cucu, Konsep Strategi Pembelajaran, Bandung: Refika Aditama, 2010.

Sukmadinata, Nana Syaodih, Landasan Psikologi Proses Pendidikan, Bandung: Remaja Rosdakarya, 2007.

, Pengembangan Kurikulum: Teori dan Praktek, Bandung: Remaja Rosdakarya, 2010.

Suryabrata, Sumadi, Psikologi Pendidikan, Jakarta: Rajawali Press, 2011.

Sutikno, Pupuh Fathurrohman dan M. Sobry, Strategi Belajar Mengajar Melalui Penanaman Konsep Umum dan Konsep Islami, Bandung: Refika Aditama, 2011.

Syah, Muhibbin, Psikologi Pendidikan Dengan Pendekatan Baru, Bandung: Remaja Rosdakarya, 2007. , Psikologi Belajar, Jakarta: Rajawali Press, 2009.

Tilaar, H.A.R., Manifesto Pendidikan Nasional: Tinjauan dari Perspektif Postmodernisme dan Studi Kultural, Jakarta: Kompas, 2005. 